\title{
Ternary Ni-Co-Fe Exsolved Nanoparticles/Perovskite System for Energy Applications: Nanostructure Characterization and Electrochemical Activity
}

\author{
Mariano Santaya, Horacio E. Troiani,* Alberto Caneiro, and Liliana V. Mogni
}

Cite This: https://dx.doi.org/10.1021/acsaem.0c01997

Read Online

\section{ACCESS}

山 Metrics \& More

Article Recommendations

ABSTRACT: The exsolution of Ni-Co-Fe from a $\mathrm{Sr}_{0.93}\left(\mathrm{Ti}_{0.3} \mathrm{Fe}_{0.56} \mathrm{Ni}_{0.07} \mathrm{Co}_{0.07}\right) \mathrm{O}_{3-\delta}$ perovskite (STFNC) is explored as a strategy to produce electrochemically active electrodes for symmetric-SOFC (S-SOFC). It was found that a nanostructured $\mathrm{NiCoFe}$ ternary alloy phase, with approximately equal amounts of each metal, can be formed by this method. The STFNC electrode is studied via electrochemical impedance spectroscopy, showing a really interesting potential as S-SOFC electrode: the anode polarization resistance was $1.12 \Omega \cdot \mathrm{cm}^{2}$ in a wet $10 \% \mathrm{H}_{2}$ atmosphere at 700 ${ }^{\circ} \mathrm{C}$ (exsolving in situ the $\mathrm{NiCoFe}$ phase), and the cathode polarization resistance at $700{ }^{\circ} \mathrm{C}$ in air was 0.054 and $0.042 \Omega \cdot \mathrm{cm}^{2}$, before and after exsolution, respectively.

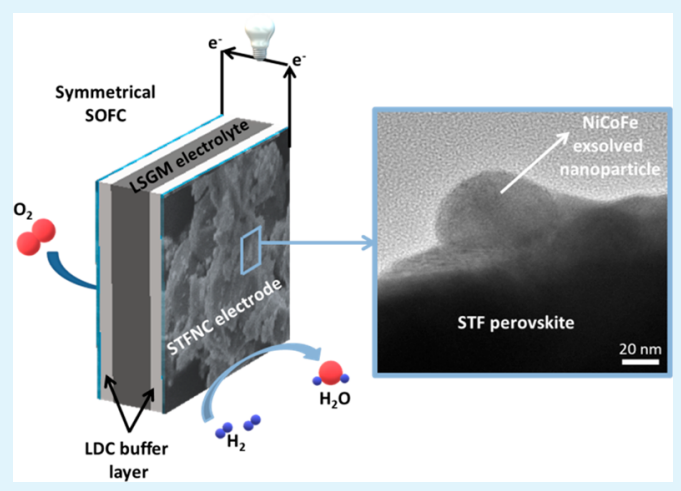

KEYWORDS: exsolution, perovskite, ternary alloy, symmetric-SOFC

$\mathrm{E}$ xsolution has been intensively studied in the fields of energy materials for conversion and storage as a method for the preparation of catalytically active and durable metal nanoparticles. ${ }^{1}$ This method consists of the segregation of easily reducible metals that are originally contained in an oxide lattice and diffuse to the surface, forming nanoparticles when exposed to reducing conditions at high temperatures. The particularity of this method is that exsolved nanoparticles remain attached to the surface of the original phase, forming a "socket" between the particle and the host oxide. ${ }^{2}$ Socketing constitutes an important issue: it prevents undesired coarsening, with its consequent reduction of the nanoparticles' surface area, and it increases the stability of the system. Exsolution also induces modifications in the original parent matrix; these modifications are constituted by the obvious change in chemical composition and by the possible structural and nanostructural modifications after segregation of the exsolved phase. ${ }^{3}$ Particularly, the area of solid oxide fuel cells (SOFC) is under exploration for this approach to obtain alternative anode materials with better performance for lowand intermediate-temperature SOFCs, but specifically with better stability under carbon-rich fuel atmospheres in comparison to the state of the art Ni-YSZ anode. ${ }^{4}$ In this sense, also these kinds of materials based in oxides could operate in a symmetrical cell configuration, working alternatively as anode and cathode. ${ }^{5}$ This is especially interesting for materials that could be regenerated under redox cycles, known as smart materials, ${ }^{6}$ because it could extend the lifetimes of cells.

Most of the previous works on exsolution show the formation of single metal phases or even binary alloys. Examples of single metal exsolved phases can be found in samples with only one easily reducible B-site cation accompanied by stable nonreducible cations, as is the case for $\mathrm{Ni}$ exsolution from $\mathrm{La}_{0.52} \mathrm{Sr}_{0.28} \mathrm{Ni}_{0.06} \mathrm{Ti}_{0.94} \mathrm{O}_{3-\delta}{ }^{7}$ or $\mathrm{Fe}$ exsolution in $\left(\mathrm{La}_{0.75} \mathrm{Sr}_{0.25}\right)_{0.85}\left(\mathrm{Cr}_{0.5} \mathrm{Fe}_{0.5}\right)_{0.85} \mathrm{Fe}_{0.15} \mathrm{O}_{3-\delta}{ }^{8}$ Exsolution in these works is achieved after reduction in dry $5 \% \mathrm{H}_{2}$ atmospheres at 900 and $800{ }^{\circ} \mathrm{C}$, respectively. As for bimetallic alloy exsolution, $\mathrm{Fe}-\mathrm{Ni}$ nanoparticles were exsolved from single perovskites as reported previously by our group in $\mathrm{Sr}_{x}\left(\mathrm{Ti}_{0.3} \mathrm{Fe}_{0.63} \mathrm{Ni}_{0.07}\right) \mathrm{O}_{3-\delta}{ }^{3,4}$ and also from double perovskites as in $\mathrm{Sr}_{2} \mathrm{Fe}_{1.4} \mathrm{Ni}_{0.1} \mathrm{Mo}_{0.5} \mathrm{O}_{6-\delta}$, ${ }^{9}$ with reductions at 850 to $800{ }^{\circ} \mathrm{C}$ in humidified $\mathrm{H}_{2}$ atmospheres; also $\mathrm{Fe}-\mathrm{Co}$ binary alloys were exsolved from $\mathrm{La}_{0.4} \mathrm{Sr}_{0.6} \mathrm{Fe}_{0.7} \mathrm{Ti}_{0.3-x} \mathrm{Co}_{x} \mathrm{O}_{3-\delta}{ }^{5}$ and $\mathrm{La}_{0.5} \mathrm{Sr}_{0.5} \mathrm{Co}_{0.45} \mathrm{Fe}_{0.45} \mathrm{Nb}_{0.1} \mathrm{O}_{3-\delta},{ }^{10}$ after reducing in wet $\mathrm{H}_{2}$ atmospheres at 850 and $750{ }^{\circ} \mathrm{C}$, respectively, and from Co/ $\mathrm{Fe}$ co-doped perovskites such as $\mathrm{La}_{0.5} \mathrm{Ba}_{0.5} \mathrm{MnO}_{3-\delta}{ }^{11}$ and

Received: August 18, 2020

Accepted: September 24, 2020

Published: September 24, 2020 
(a)

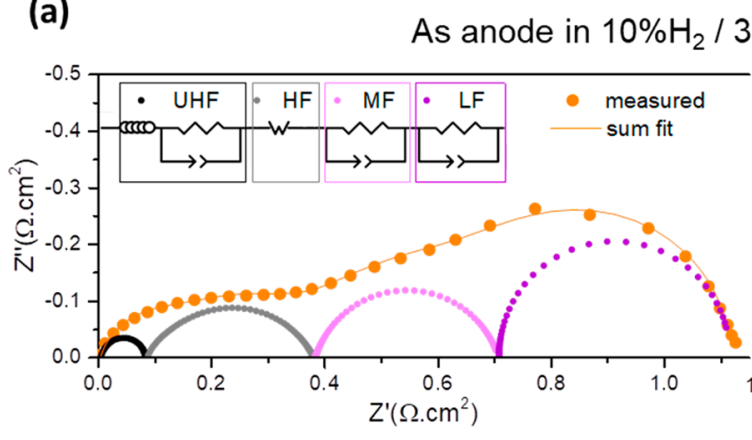

$\% \mathrm{H}_{2} \mathrm{O} / 87 \% \mathrm{Ar}$

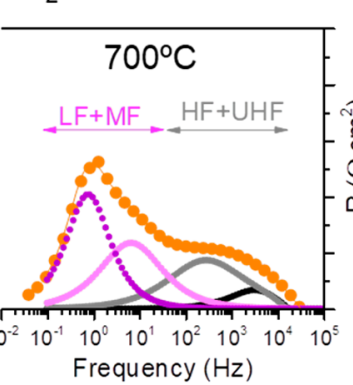

(b)

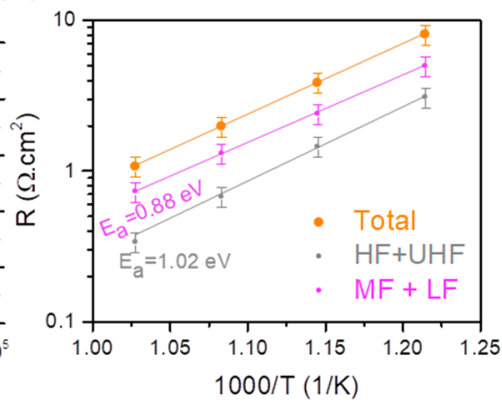

(c)

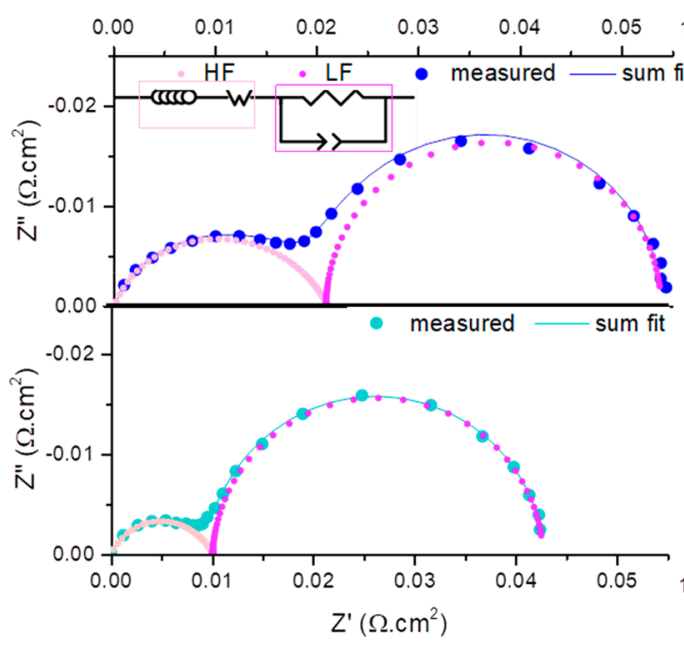

As cathode in air

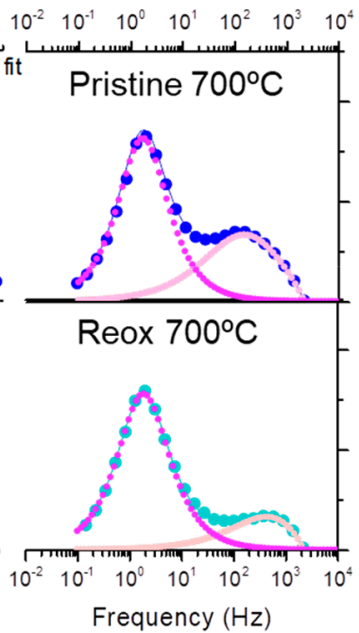

(d)

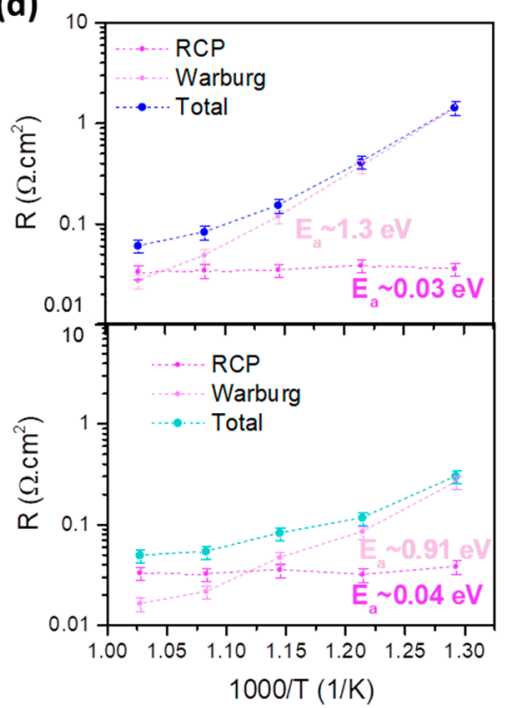

Figure 1. (a) Nyquist and Bode plots of the symmetrical cell using STFNC as anode at $700{ }^{\circ} \mathrm{C}$ in a $10 \% \mathrm{H}_{2} / 3 \% \mathrm{H}_{2} \mathrm{O} / 87 \% \mathrm{Ar}$ atmosphere, with the equivalent circuit used for fitting. (b) Arrhenius plot of the $R_{\mathrm{MF}+\mathrm{LF}}$ and $R_{\mathrm{HF}+\mathrm{UHF}}$ contributions along with the total resistance. (c) Cathode Nyquist and Bode graphs at $700{ }^{\circ} \mathrm{C}$ in air for both the pristine and re-ox electrodes (equivalent circuit in the inset). (d) Arrhenius dependence of these contributions.

$\mathrm{Sr}_{2} \mathrm{Fe}_{1.5} \mathrm{Mo}_{0.5} \mathrm{O}_{6-\delta}$ double perovskite, ${ }^{12}$ using dry $5 \% \mathrm{H}_{2}$ atmospheres at 850 and $800{ }^{\circ} \mathrm{C}$, respectively. In all cases the authors highlight the good catalytic activity of the exsolved nanoparticles, and some of them also remark on their high resistance to carbon deposition under C-based fuel operation. ${ }^{71}$ It can be noted that different atmospheres and temperature conditions for exsolution are used in these works, generally finding more aggressive reduction conditions for single metal exsolution and softer conditions for bimetallics. Different reduction conditions are needed for different cases since exsolution depends on many factors such as A-site deficiency, ${ }^{3,13}$ the sample microstructure, ${ }^{14}$ and the reducibility of the exsolved cation (e.g., $\mathrm{Ni}$ and $\mathrm{Co}$ are easier to reduce than $\mathrm{Fe}^{15}$ ), etc.

However, there is no deep exploration on the formation of ternary alloy nanoparticles by exsolution from perovskitesbased oxides or how these nanoparticles could increase the catalytic activity. A recent study presented $\mathrm{Cu}-\mathrm{Fe}-\mathrm{Ni}$ exsolution in the form of nanosized $\mathrm{Cu}$-rich and $\mathrm{Fe}$-rich ternary alloys, exsolving from $\mathrm{Cu}_{1-x} \mathrm{Ni}_{x} \mathrm{Fe}_{2} \mathrm{O}_{4}$ spinels at $800{ }^{\circ} \mathrm{C}$ under wet $\mathrm{H}_{2}$, as a strategy to produce active SOFC anodes. ${ }^{16}$ A ternary $\mathrm{Co}-\mathrm{Ni}-\mathrm{Mo}$ alloy was also used to impregnate a $\mathrm{Sr}_{2} \mathrm{FeMoO}_{6-\delta}$ anode, ${ }^{17}$ achieving lower electrode polarization resistance $\left(R_{\mathrm{P}}\right)$ values than impregnating with precious metals such as Pd. The results found in these studies suggest that ternary alloys can be interesting alternatives to improve the catalytic activity of SOFC's anodes. It was also demonstrated that trimetallic $\mathrm{Fe}-\mathrm{Ni}-\mathrm{Co}$ nanoparticles in multiwalled carbon nanotubes showed higher activity than either $\mathrm{Fe}-\mathrm{Ni}$ and $\mathrm{Fe}-\mathrm{Co}$ bimetallic nanoparticles for the ORR, in a liquid electrolyte system. ${ }^{18}$ Here it is worth noting that in these oxidizing atmospheres the metallic nanoparticles are oxidized to $(\mathrm{Fe}, \mathrm{Ni}, \mathrm{Co}) \mathrm{O}_{x}$. Considering the mentioned potential of ternary alloys to improve catalytic activity, exsolution of $\mathrm{Ni}-$ $\mathrm{Fe}-\mathrm{Co}$ ternary alloy nanoparticles from a $\mathrm{Sr}_{0.93}\left(\mathrm{Ti}_{0.3} \mathrm{~F}_{0.54} \mathrm{Ni}_{0.07} \mathrm{Co}_{0.07}\right) \mathrm{O}_{3-\delta}$ perovskite (STFNC) is explored in this work, and electrochemical impedance spectroscopy tests are made to evaluate the electrode performance for both the fuel oxidation and $\mathrm{O}_{2}$-reduction reactions.

Figure 1a shows Nyquist and Bode plots of the cell working as anode in wet $10 \% \mathrm{H}_{2}$ at $700{ }^{\circ} \mathrm{C}$ and the equivalent circuit model used for fitting. Similar equivalent circuits have been proposed recently for these types of anodes, ${ }^{5}$ where several rate-limiting processes can be distinguished. Contributions in the ultrahigh- and high-frequency (UHF and HF) regions are usually attributed to ion and electron charge transfer processes in similar anode materials, while the middle- and lowfrequency (MF and LF) contributions are normally attributed to surface processes such as adsorption/desorption of the fuel. ${ }^{4,19}$ Figure $1 \mathrm{~b}$ shows the Arrhenius plot of the real 

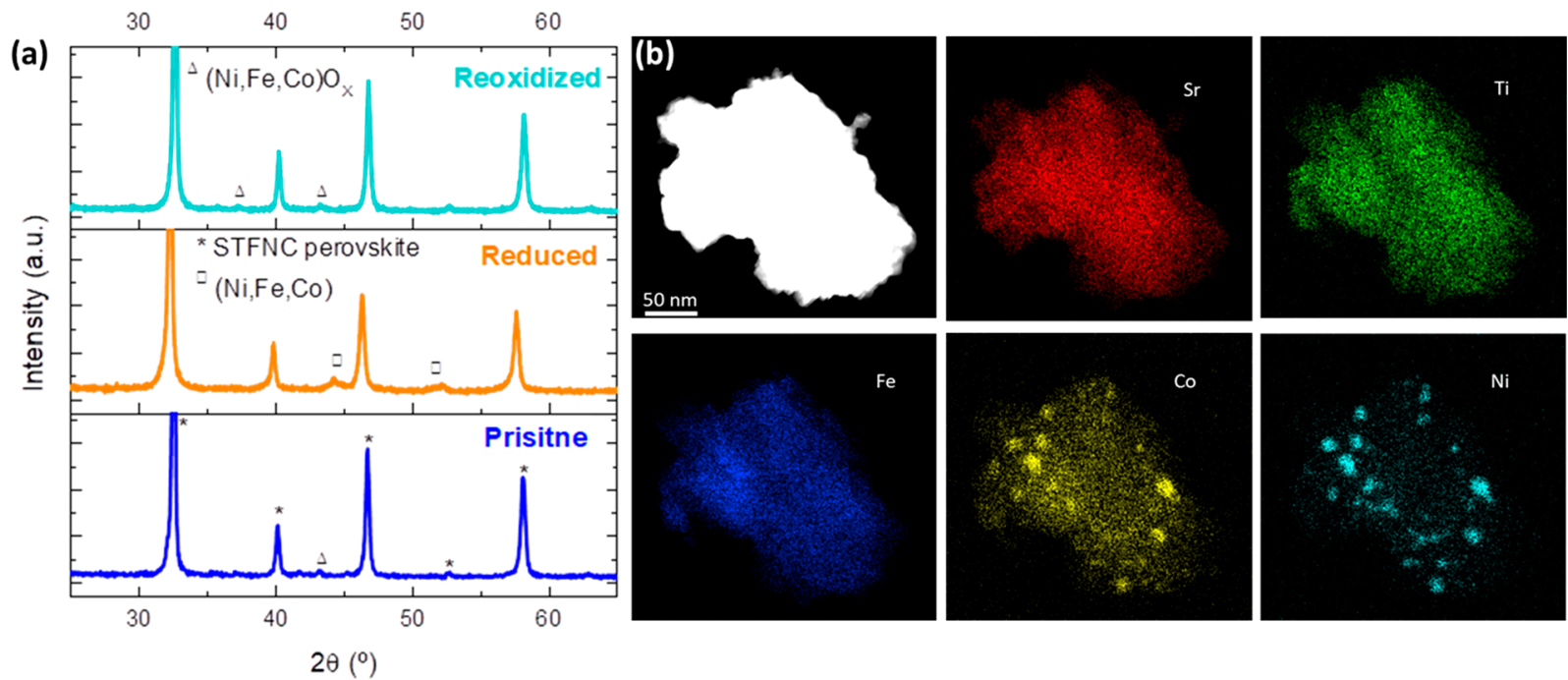

Figure 2. (a) XRD pattern of the STFNC sample before (pristine), after reduction in a $10 \% \mathrm{H}_{2} / 3 \% \mathrm{H}_{2} \mathrm{O} / 87 \%$ Ar atmosphere at $750{ }^{\circ} \mathrm{C}$ (reduced), and after reoxidation at $750{ }^{\circ} \mathrm{C}$ for $1 \mathrm{~h}$ in air (reoxidized). (b) STEM HAADF image and EDS maps of $\mathrm{Sr}, \mathrm{Ti}, \mathrm{Fe}, \mathrm{Co}$, and $\mathrm{Ni}$ of the reduced sample.

contribution of MF and LF arcs added together $\left(R_{\mathrm{MF}+\mathrm{LF}}\right)$ and the same for the $R_{\mathrm{HF}+\mathrm{UHF}}$ arcs since these contributions are difficult to separate from one another. Both $R_{\mathrm{MF}+\mathrm{LF}}$ and $R_{\mathrm{HF}+\mathrm{UHF}}$ show an Arrhenius type temperature dependence with relatively low activation energies.

Figure 1c shows Nyquist and Bode plots of the STFNC cell working as cathode in air (pristine and re-ox cathode) at 700 ${ }^{\circ} \mathrm{C}$, together with the equivalent circuit model. Two arcs are easily distinguishable, labeled as high- and low-frequency contributions (HF and LF). The Arrhenius plot of each contribution along with the total resistance $\left(R_{\text {tot }}\right)$ is shown in Figure $1 \mathrm{~d}$. The $R_{\mathrm{LF}}$ arc can be attributed to $\mathrm{O}_{2}$ gas diffusion according to its high capacitance values and low activation energy $\left(C \sim 3 \mathrm{~F} \cdot \mathrm{cm}^{-2} ; E_{\mathrm{a}} \sim 0.03 \mathrm{eV}\right)$. As expected for gas diffusion, this $R_{\mathrm{LF}}$ follows the same behavior for both pristine and re-ox cathode. However, the high-frequency arc, fitted with a Warburg type circuit element $\left(R_{\mathrm{W}}\right)$, is significantly improved from the pristine to the reox cathode conditions; e.g., at 700 ${ }^{\circ} \mathrm{C} R_{\mathrm{W}}$ decreases around $67 \%$, whereas at $500{ }^{\circ} \mathrm{C}$ it decreases as much as $\sim 428 \%$. Then, this contribution is probably due to a co-limiting process involving $\mathrm{O}$-ion diffusion and a surface exchange process, which is improved by surface modification induced by the redox cycle.

The anode polarization resistance $\left(R_{\mathrm{P}, \mathrm{A}}\right)$ values measured for STFNC were $1.12 \Omega \cdot \mathrm{cm}^{2}\left(700{ }^{\circ} \mathrm{C}\right)$ and $3.93 \Omega \cdot \mathrm{cm}^{2}\left(600{ }^{\circ} \mathrm{C}\right)$ in a wet $10 \% \mathrm{H}_{2}$ atmosphere, and the cathode polarization resistance $\left(R_{\mathrm{P}, \mathrm{C}}\right)$ values measured in air were $0.054 \Omega \cdot \mathrm{cm}^{2}$ $\left(700{ }^{\circ} \mathrm{C}\right)$ and $0.14 \Omega \cdot \mathrm{cm}^{2}\left(600{ }^{\circ} \mathrm{C}\right)$ before reduction, with a significant improvement to $0.042 \Omega \cdot \mathrm{cm}^{2}\left(700{ }^{\circ} \mathrm{C}\right)$ and 0.071 $\Omega \cdot \mathrm{cm}^{2}\left(600{ }^{\circ} \mathrm{C}\right)$ after reduction/reoxidation was performed. These values suggest that STFNC could be a potential electrode material for intermediate-temperatures symmetricSOFC. Larger resistance values were found for a $\mathrm{SrTi}_{0.3} \mathrm{Fe}_{0.7} \mathrm{O}_{3-\delta}$ sample prepared by the same sol-gel method, ${ }^{14}$ with $R_{\mathrm{P}}$ values at $700{ }^{\circ} \mathrm{C}$ of $0.45 \Omega \cdot \mathrm{cm}^{2}$ as cathode and of $7.89 \Omega \cdot \mathrm{cm}^{2}$ as anode also in a wet $10 \% \mathrm{H}_{2}$ atmosphere. Also, larger resistance values are usually found for other electrodes proposed as candidates for symmetric-SOFC such as chromites $\mathrm{La}_{0.75} \mathrm{Sr}_{0.25} \mathrm{Cr}_{0.5} \mathrm{Mn}_{0.5} \mathrm{O}_{3--\delta}{ }^{20}$ also for $\mathrm{La}_{0.8} \mathrm{Sr}_{0.2} \mathrm{FeO}_{3-\delta}$ ferrites, ${ }^{21}$ Co-doped $\mathrm{La}_{0.8} \mathrm{Sr}_{1.2} \mathrm{Fe}_{0.9} \mathrm{Co}_{0.1} \mathrm{O}_{4-\delta}$ double perovskite, ${ }^{22}$ and for $\operatorname{Pr}_{0.6} \mathrm{Sr}_{0.4} \mathrm{Fe}_{0.8} \mathrm{Ni}_{0.2} \mathrm{O}_{3-\delta}$ materials. ${ }^{23}$ A recent study ${ }^{5}$ showed a similar $\mathrm{La}_{0.4} \mathrm{Sr}_{0.6} \mathrm{Fe}_{0.7} \mathrm{Ti}_{0.25} \mathrm{Co}_{0.05} \mathrm{O}_{3-\delta}$ perovskite with a $R_{\mathrm{P}, \mathrm{A}}$ of $\sim 0.8 \Omega \cdot \mathrm{cm}^{2}$ at $700{ }^{\circ} \mathrm{C}$ as anode in pure humidified $\mathrm{H}_{2}$, and a $R_{\mathrm{P}, \mathrm{C}}$ of $0.1 \Omega \cdot \mathrm{cm}^{2}$ as cathode at 750 ${ }^{\circ} \mathrm{C}$ in air. A $\mathrm{SrFe}_{0.8} \mathrm{~W}_{0.2} \mathrm{O}_{3-\delta}$ electrode was also recently investigated, ${ }^{19}$ reporting $R_{\mathrm{P}, \mathrm{A}}$ values of $0.2 \Omega \cdot \mathrm{cm}^{2}$ in pure wet $\mathrm{H}_{2}$ and a $R_{\mathrm{P}, \mathrm{C}}$ of $0.084 \Omega \cdot \mathrm{cm}^{2}$ in air, but these were obtained at temperatures of $800{ }^{\circ} \mathrm{C}$. Comparison of STFNC electrode with the materials in the literature gives very promising results, with a reasonably good anode performance considering the soft reducing atmosphere used (humidified $10 \% \mathrm{H}_{2}$ ) and the low temperatures (up to $700{ }^{\circ} \mathrm{C}$ ), and with a remarkable cathode performance, with lower $R_{\mathrm{P}}$ values than that of the $S$ SOFC electrodes previously cited.

The improvement of cathodic performance for the re-ox, compared to the pristine STFNC, can be attributed to the changes induced in the sample after exsolution. Figure $2 \mathrm{a}$ shows the X-ray diffraction (XRD, Panalytical Empyrean diffractometer with $\mathrm{Cu} \mathrm{K} \alpha$ radiation) patterns of the STFNC sample before and after reduction at $750{ }^{\circ} \mathrm{C}$ in a wet $10 \% \mathrm{H}_{2}$ atmosphere for $4 \mathrm{~h}$ (labeled pristine and reduced, respectively), and after reoxidation for $1 \mathrm{~h}$ in air at $750{ }^{\circ} \mathrm{C}$ (reoxidized). The perovskite peaks shift to the left in the reduced sample, indicating a higher lattice parameter, which can be the result of accommodating $\mathrm{O}$ vacancies after the reduction process, and of the modified stoichiometry after metal exsolution. A metallic phase matching $\mathrm{Ni} / \mathrm{Fe} / \mathrm{Co} \mathrm{FCC}$ structure can be identified in this reduced sample and is no longer present in the reoxidized case, whereas small peaks associated with the formation of transition metal oxide with FCC structure are observed. This suggests that the nanoparticles become fully oxidized after the $1 \mathrm{~h}$ reoxidation treatment at $750{ }^{\circ} \mathrm{C}$. The metallic phase observed in the reduced sample is further confirmed by a STEM-EDS map shown in Figure 2b (TEM TALOS F200X equipped with 4 windowless SDD Super-X EDS detector system). The different chemical elements are identified with nanometer resolution, which allows one to obtain detailed information about the nanoparticle's composition and sizes (ranging from $\sim 10$ to $\sim 40 \mathrm{~nm})$. 

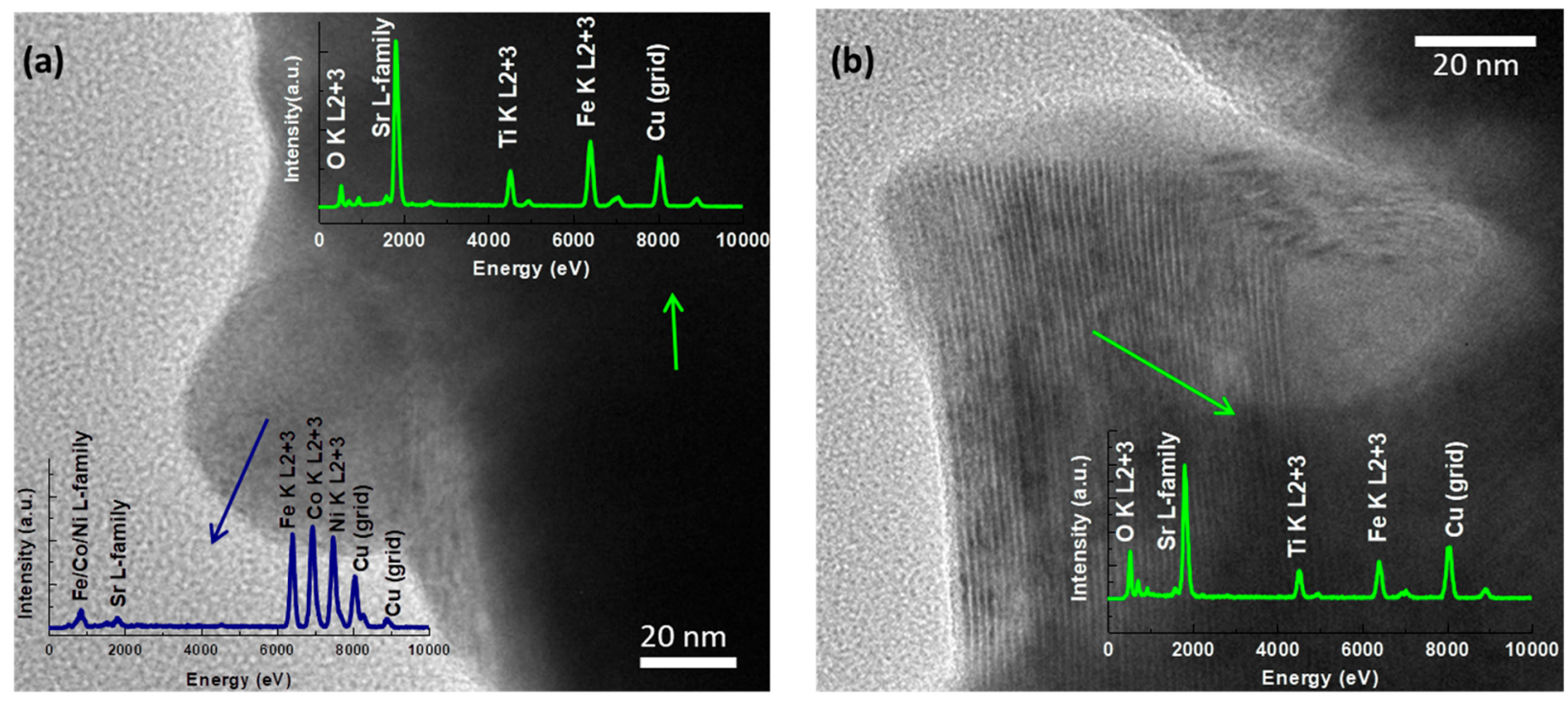

Figure 3. Bright field TEM images of (a) exsolved nanoparticle with the corresponding EDS punctual analysis and (b) remaining layered perovskite with Sr excess.

Nanoparticles with high concentrations of $\mathrm{Ni}$ and Co can be distinguished from the parent oxide with the EDS mapping. The situation is not as clear in the Fe map, since the perovskite matrix still contains plenty of $\mathrm{Fe}$ after exsolution and thus there is no contrast between the nanoparticles and the oxide. For this reason, a punctual EDS analysis over one nanoparticle is shown in Figure 3a (FEI TECNAI F20 microscope). This analysis reveals that the nanoparticle is formed with approximately equal amounts of $\mathrm{Ni}, \mathrm{Fe}$, and $\mathrm{Co}$. The fact that $\mathrm{Ni}, \mathrm{Fe}$, and $\mathrm{Co}$ do not exsolve separately to form isolated particles, but are instead found forming a homogeneous ternary nanostructured phase, may lead to new questions regarding the exsolution mechanisms: do these metals exsolve together once a diffusion path is formed? Or do they exsolve separately and then aggregate on the surface, as was suggested by Kwon et al.? ${ }^{24}$ Answers to these questions may be found with advanced materials science techniques such as in situ microscopy, as was studied for single metal $\mathrm{Ni}$ exsolution from $\mathrm{La}_{0.43} \mathrm{Ca}_{0.37} \mathrm{Ti}_{0.94} \mathrm{Ni}_{0.06} \mathrm{O}_{3-\delta}$. ${ }^{25}$

Punctual EDS analysis was also performed over the parent oxide, revealing that there is no $\mathrm{Ni}$ nor $\mathrm{Co}$ left in the perovskite, in contrast to the EDS map of Figure $2 \mathrm{~b}$ for $\mathrm{Ni}$ and Co (although there the signal could be due to a noise contribution). In the following we will assume that almost all of the $\mathrm{Ni}$ and Co segregates to the surface, and thus there is no $\mathrm{Ni}$ or $\mathrm{Co}$ left in the perovskite after exsolution. Then, considering that the exsolved alloy contains almost equal amounts of $\mathrm{Ni}, \mathrm{Co}$, and $\mathrm{Fe}$ and that all of the $\mathrm{Ni}$ and $\mathrm{Co}$ are exsolved, we can state that approximately 0.07 of each of these metals left the B-site of the perovskite to form metallic nanoparticles. This reaction is described in eq 1 .

$$
\begin{aligned}
& \mathrm{Sr}_{0.93}\left(\mathrm{Ti}_{0.3} \mathrm{Fe}_{0.56} \mathrm{Ni}_{0.07} \mathrm{Co}_{0.07}\right) \mathrm{O}_{3-\delta} \\
& \stackrel{\text { exsolution }}{\longrightarrow} 0.07 \mathrm{NiFeCo}+0.93 \mathrm{Sr}\left(\mathrm{Ti}_{0.32} \mathrm{Fe}_{0.53}\right) \mathrm{O}_{3-\delta^{\prime}}+x \mathrm{O}_{2}
\end{aligned}
$$

Thus, the resulting perovskite has an equivalent $\mathrm{AB}_{0.85} \mathrm{O}_{3-\delta}$ stoichiometry. Although this result is not exact and comes from a series of assumptions, it serves to illustrate that there is a $\mathrm{Sr}$ excess after exsolution. The sample can accommodate this $\mathrm{Sr}$ excess by segregation of $\mathrm{SrO}$ (reaction 2) or by forming a layered perovskite (reaction 3), as well as a combination of these two possibilities.

$$
\mathrm{Sr}(\mathrm{Ti}, \mathrm{Fe})_{0.85} \mathrm{O}_{3-\delta^{\prime}} \rightarrow 0.15 \mathrm{SrO}+0.85 \mathrm{Sr}(\mathrm{Ti}, \mathrm{Fe}) \mathrm{O}_{3-\delta^{\prime \prime}}
$$

$$
\begin{aligned}
& \mathrm{Sr}(\mathrm{Ti}, \mathrm{Fe})_{0.85} \mathrm{O}_{3-\delta^{\prime}} \\
& \quad \rightarrow 0.15 \mathrm{Sr}_{2}(\mathrm{Ti}, \mathrm{Fe}) \mathrm{O}_{4 \pm \delta^{\prime \prime \prime}}+0.7 \mathrm{Sr}(\mathrm{Ti}, \mathrm{Fe}) \mathrm{O}_{3-\delta^{\prime \prime}}
\end{aligned}
$$

In fact, Figure $3 \mathrm{~b}$ shows a HR-TEM image over a zone of the sample where a fringe pattern with a periodicity of $\sim 13 \AA$ can be observed, suggesting the formation of a layered structure, compatible with an $n=1$ Ruddlesden-Popper phase $\mathrm{Sr}_{2}(\mathrm{Ti}, \mathrm{Fe}) \mathrm{O}_{4}$. The corresponding EDS analysis reveals a Srrich composition for this area. Although the exact configuration of the resulting sample is not clear, the fact that there is an excess of $\mathrm{Sr}$ after exsolution is evident and it is a potential drawback to electrochemical performance. On the other hand, since exsolution itself is beneficial to electrochemical performance, the combination of these two effects gives a more complex result. Also, the Sr excess could be detrimental to the SOFC performance after long-term operation. Trying different amounts of $\mathrm{Ni}$ and $\mathrm{Co}$ doping could give a better compromise between the amount of exsolved metal phase and the Sr excess that remains after exsolution.

As a summary, exsolution of $\mathrm{NiCoFe}$ ternary alloy nanoparticles from a STF-based perovskite was achieved. Surprisingly, these metals were seen to exsolve together, forming a unique NiFeCo phase with similar amounts of each metal. Electrochemical impedance spectroscopy tests were performed with the STFNC sample before (pristine) and after exsolution (re-ox), observing an improved performance for the re-ox sample. However, the exsolution of a large amount of Bsite metals results in a $\mathrm{Sr}$ excess after exsolution, which could affect negatively the cell performance after long-term operation. Experimenting with different amounts of $\mathrm{Ni}$ and Co doping could be a key to finding a better compromise between the amount of exsolved metals and the $\mathrm{Sr}$ excess that remains after exsolution. In any case, we believe that exsolution of ternary alloy phases is a very interesting phenomenon to be 
explored and with a high potential applicability in the field of electrochemistry.

\section{EXPERIMENTAL METHODS}

The STFNC was prepared by a glycine combustion sol-gel method adapted from ref 14 and using titanium butoxide $\left(\mathrm{C}_{16} \mathrm{H}_{36} \mathrm{O}_{4} \mathrm{Ti}\right)$, $\mathrm{SrCO}_{3}, \mathrm{Fe}\left(\mathrm{NO}_{3}\right)_{3} \cdot 9 \mathrm{H}_{2} \mathrm{O}, \mathrm{Ni}\left(\mathrm{NO}_{3}\right)_{2} \cdot 6 \mathrm{H}_{2} \mathrm{O}$, and $\mathrm{Co}\left(\mathrm{NO}_{3}\right)_{2} \cdot 6 \mathrm{H}_{2} \mathrm{O}$ as starting materials. The resulting powder was treated for $6 \mathrm{~h}$ at $850{ }^{\circ} \mathrm{C}$ and deposited on $\mathrm{La}_{0.8} \mathrm{Sr}_{0.2} \mathrm{Ga}_{0.8} \mathrm{Mg}_{0.2} \mathrm{O}_{3}$ (LSGM) dense electrolyte. A buffer layer of $\mathrm{La}_{0.4} \mathrm{Ce}_{0.6} \mathrm{O}_{2-\delta}$ (LDC) was previously deposited over the electrolyte surface, to avoid chemical reaction between the LSGM electrolyte and the STFNC electrode. ${ }^{14}$ The electrode ink was spin coated over the LSGM/LDC electrolyte and fired at $1000{ }^{\circ} \mathrm{C}$ for 1.5 h. A silver grid was painted on top of the electrodes, and gold contacts were used on top as current collectors. Electrochemical impedance spectroscopy (EIS) tests were performed on symmetrical cell STFNC/LDC/LSGM/LDC/STFNC electrodes by using an Autolab PGSTAT32/FRA2 potentiostat and frequency analyzer, with frequencies ranging from $1 \mathrm{MHz}$ to $10 \mathrm{mHz}$, and with $10 \mathrm{mV} \mathrm{AC}$ perturbation and no DC bias. EIS measurements were carried out in air, raising the temperature to $700{ }^{\circ} \mathrm{C}$ (pristine cathode). Then, STFNC was reduced at $700{ }^{\circ} \mathrm{C}$ in a $10 \% \mathrm{H}_{2} / 3 \% \mathrm{H}_{2} \mathrm{O} / 87 \% \mathrm{Ar}$ atmosphere to exsolve the metallic nanoparticles (exsolved anode), which was evaluated as a function of temperature between 700 and $550{ }^{\circ} \mathrm{C}$ in this reducing atmosphere. Afterward, the electrode was reoxidated and measured again in air (re-ox cathode).

\section{AUTHOR INFORMATION}

\section{Corresponding Author}

Horacio E. Troiani - Departmento Caracterización de Materiales, CNEA-CONICET, Centro Atómico Bariloche, CP8400 San Carlos de Bariloche, Argentina; Instituto Balseiro, Universidad Nacional de Cuyo, R8402AGP San Carlos de Bariloche, Argentina; $\odot$ orcid.org/0000-0002-2259-3252; Email: troiani@cab.cnea.gov.ar

\section{Authors}

Mariano Santaya - Departmento Caracterización de Materiales, Instituto de Nanociencia y Nanotecnologia, CNEA-CONICET, Centro Atómico Bariloche, CP8400 San Carlos de Bariloche, Argentina

Alberto Caneiro - Y-TEC, YPF Tecnologia, CP1923 Berisso, Argentina

Liliana V. Mogni - Departmento Caracterizacion de Materiales, Instituto de Nanociencia y Nanotecnologia, CNEA-CONICET, Centro Atómico Bariloche, CP8400 San Carlos de Bariloche, Argentina; Instituto Balseiro, Universidad Nacional de Cuyo, R8402AGP San Carlos de Bariloche, Argentina

Complete contact information is available at: https://pubs.acs.org/10.1021/acsaem.0c01997

\section{Funding}

We received, funding from Consejo Nacional de Investigaciones Cientificas y Técnicas (CONICET) Grant PIP-0565, the Agencia Nacional de Promoción de Ciencia y Tecnologia (ANPCyT) Grant PICT 2016-2965, the Comision Nacional de Energia Atómica (Grant PAC 2019-2020), and the Instituto Balseiro-Universidad Nacional de Cuyo (Grants 06/C583 and 06/C601).

\section{Notes}

The authors declare no competing financial interest.

\section{ACKNOWLEDGMENTS}

We acknowledge Y-TEC for the use of the Talos F200X microscope.

\section{REFERENCES}

(1) Rosen, B. A. Progress and Opportunities for Exsolution in Electrochemistry. Electrochem 2020, 1, 32-43.

(2) Oh, T. S.; Rahani, E. K.; Neagu, D.; Irvine, J. T. S.; Shenoy, V. B.; Gorte, R. J.; Vohs, J. M. Evidence and Model for Strain-Driven Release of Metal Nanocatalysts from Perovskites during Exsolution. J. Phys. Chem. Lett. 2015, 6, 5106-5110.

(3) Zhu, T.; Troiani, H. E.; Mogni, L. V.; Santaya, M.; Han, M.; Barnett, S. A. Exsolution and electrochemistry in perovskite solid oxide fuel cell anodes: Role of stoichiometry in $\mathrm{Sr}(\mathrm{Ti}, \mathrm{Fe}, \mathrm{Ni}) \mathrm{O}_{3}$. J. Power Sources 2019, 439, 227077.

(4) Zhu, T.; Troiani, H. E.; Mogni, L. V.; Han, M.; Barnett, S. A. NiSubstituted $\mathrm{Sr}(\mathrm{Ti}, \mathrm{Fe}) \mathrm{O}_{3}$ SOFC Anodes: Achieving High Performance via Metal Alloy Nanoparticle Exsolution. Joule 2018, 2, 478-496.

(5) Song, J.; Zhu, T.; Chen, X.; Ni, W.; Zhong, Q. Cobalt and Titanium substituted $\mathrm{SrFeO}_{3}$ based perovskite as efficient symmetrical electrode for solid oxide fuel cell. J. Mater. 2020, 6, 377-384.

(6) Burnat, D.; Kontic, R.; Holzer, L.; Steiger, P.; Ferri, D.; Heel, A. Smart material concept: Reversible microstructural self-regeneration for catalytic applications. J. Mater. Chem. A 2016, A4, 11939-11948.

(7) Neagu, D.; Oh, T. S.; Miller, D. N.; Ménard, H.; Bukhari, S. M.; Gamble, S. R.; Gorte, R. J.; Vohs, J. M.; Irvine, J. T. S. Nano-socketed nickel particles with enhanced coking resistance grown in situ by redox exsolution. Nat. Commun. 2015, 6, 8120.

(8) Li, Y.; Wang, Y.; Doherty, W.; Xie, K.; Wu, Y. Perovskite chromates cathode with exsolved iron nanoparticles for direct hightemperature steam electrolysis. ACS Appl. Mater. Interfaces 2013, 5, $8553-8562$.

(9) Liu, T.; Zhao, Y.; Zhang, X.; Zhang, H.; Jiang, G.; Zhao, W.; Guo, J.; Chen, F.; Yan, M.; Zhang, Y.; Wang, Y. Robust redoxreversible perovskite type steam electrolyser electrode decorated with: In situ exsolved metallic nanoparticles. J. Mater. Chem. A 2020, A8, $582-591$.

(10) Chen, X.; Ni, W.; Wang, J.; Zhong, Q.; Han, M.; Zhu, T. Exploration of $\mathrm{Co}-\mathrm{Fe}$ alloy precipitation and electrochemical behavior hysteresis using Lanthanum and Cobalt co-substituted $\mathrm{SrFeO}_{3-\delta}$ SOFC anode. Electrochim. Acta 2018, 277, 226-234.

(11) Hou, N.; Yao, T.; Li, P.; Yao, X.; Gan, T.; Fan, L.; Wang, J.; Zhi, X.; Zhao, Y.; Li, Y. A-site ordered double perovskite with in situ exsolved core-shell nanoparticles as anode for solid oxide fuel cells. ACS Appl. Mater. Interfaces 2019, 11, 6995-7005.

(12) Lv, H.; Lin, L.; Zhang, X.; Song, Y.; Matsumoto, H.; Zeng, C.; Ta, N.; Liu, W.; Gao, D.; Wang, G.; Bao, X. In Situ Investigation of Reversible Exsolution/Dissolution of CoFe Alloy Nanoparticles in a Co-Doped $\mathrm{Sr}_{2} \mathrm{Fe}_{1.5} \mathrm{Mo}_{0.5} \mathrm{O}_{6-\delta}$ Cathode for $\mathrm{CO}_{2}$ Electrolysis. $\mathrm{Adv}$. Mater. 2020, 32, 1906193.

(13) Neagu, D.; Tsekouras, G.; Miller, D. N.; Menard, H.; Irvine, J. $\mathrm{T}$. In situ growth of nanoparticles through control of nonstoichiometry. Nat. Chem. 2013, 5, 916-923.

(14) Santaya, M.; Toscani, L.; Baqué, L.; Troiani, H. E.; Mogni, L. V. Study of phase stability of $\mathrm{SrTi}_{0.3} \mathrm{Fe}_{0.7} \mathrm{O}_{3-\delta}$ perovskite in reducing atmosphere: Effect of microstructure. Solid State Ionics 2019, 342, 115064.

(15) Kwon, O.; Sengodan, S.; Kim, K.; Kim, G.; Jeong, H. Y.; Shin, J.; Ju, Y. W.; Han, J. W.; Kim, G. Exsolution trends and co-segregation aspects of self-grown catalyst nanoparticles in perovskites. Nat. Commun. 2017, 8, 15967.

(16) Kang, B.; Matsuda, J.; Ishihara, T. Cu-Fe-Ni nano alloy particles obtained by exsolution from $\mathrm{Cu}(\mathrm{Ni}) \mathrm{Fe}_{2} \mathrm{O}_{4}$ as active anode for SOFCs. J. Mater. Chem. A 2019, A7, 26105-26115.

(17) Rath, M. K.; Lee, K. T. Superior electrochemical performance of non-precious Co-Ni-Mo alloy catalyst-impregnated $\mathrm{Sr}_{2} \mathrm{FeMoO}_{6-\delta}$ as an electrode material for symmetric solid oxide fuel cells. Electrochim. Acta 2016, 212, 678-685. 
(18) Kazakova, M. A.; Morales, D. M.; Andronescu, C.; Elumeeva, K.; Selyutin, A. G.; Ishchenko, A. V.; Golubtsov, G. V.; Dieckhöfer, S.; Schuhmann, W.; Masa, J. $\mathrm{Fe} / \mathrm{Co} / \mathrm{Ni}$ mixed oxide nanoparticles supported on oxidized multi-walled carbon nanotubes as electrocatalysts for the oxygen reduction and the oxygen evolution reactions in alkaline media. Catal. Today 2019, 0-1.

(19) Cao, Y.; Zhu, Z.; Zhao, Y.; Zhao, W.; Wei, Z.; Liu, T. Development of tungsten stabilized $\mathrm{SrFe}_{0.8} \mathrm{~W}_{0.2} \mathrm{O}_{3-\delta}$ material as novel symmetrical electrode for solid oxide fuel cells. J. Power Sources 2020, 455, 227951.

(20) Ruiz-Morales, J. C.; Canales-Vázquez, J.; Peña-Martínez, J.; López, D. M.; Núñez, P. On the simultaneous use of $\mathrm{La}_{0.75} \mathrm{Sr}_{0.25} \mathrm{Cr}_{0.5} \mathrm{Mn}_{0.5} \mathrm{O}_{3-\delta}$ as both anode and cathode material with improved microstructure in solid oxide fuel cells. Electrochim. Acta 2006, 52, 278-284.

(21) Tian, D.; Lin, B.; Yang, Y.; Chen, Y.; Lu, X.; Wang, Z.; Liu, W.; Traversa, E. Enhanced performance of symmetrical solid oxide fuel cells using a doped ceria buffer layer. Electrochim. Acta 2016, 208, 318-324.

(22) Zhou, J.; Shin, T. H.; Ni, C.; Chen, G.; Wu, K.; Cheng, Y.; Irvine, J. T. S. In Situ Growth of Nanoparticles in Layered Perovskite $\mathrm{La}_{0.8} \mathrm{Sr}_{1.2} \mathrm{Fe}_{0.9} \mathrm{Co}_{0.1} \mathrm{O}_{4-\delta}$ as an Active and Stable Electrode for Symmetrical Solid Oxide Fuel Cells. Chem. Mater. 2016, 28, 29812993.

(23) Lu, X.; Yang, Y.; Ding, Y.; Chen, Y.; Gu, Q.; Tian, D.; Yu, W.; Lin, B. Mo-doped $\mathrm{Pr}_{0.6} \mathrm{Sr}_{0.4} \mathrm{Fe}_{0.8} \mathrm{Ni}_{0.2} \mathrm{O}_{3-\delta}$ as potential electrodes for intermediate-temperature symmetrical solid oxide fuel cells. Electrochim. Acta 2017, 227, 33-40.

(24) Kwon, O.; Kim, K.; Joo, S.; Jeong, H. Y.; Shin, J.; Han, J. W.; Sengodan, S.; Kim, G. Self-assembled alloy nanoparticles in a layered double perovskite as a fuel oxidation catalyst for solid oxide fuel cells. J. Mater. Chem. A 2018, A6, 15947-15953.

(25) Neagu, D.; Kyriakou, V.; Roiban, I. L.; Aouine, M.; Tang, C.; Caravaca, A.; Kousi, K.; Schreur-Piet, I.; Metcalfe, I. S.; Vernoux, P.; Van De Sanden, M. C.M.; Tsampas, M. N. In Situ Observation of Nanoparticle Exsolution from Perovskite Oxides: From Atomic Scale Mechanistic Insight to Nanostructure Tailoring. ACS Nano 2019, 13, 12996-13005. 